\title{
PREFACE BY THE INCOMING EDITOR
}

As the incoming editor of the Journal, I would like to acknowledge the superb work of my predecessor, Pamela S. Richards, who was editor for 14 years. The first issue under her editorial leadership was the December 1980 issue and her last is the present one. During that period she put together many fine publications and promoted the practice of publishing special issues on focused topics, such as the present one, devoted to the history of Afro-Americans in New Jersey. Other special issues under Richards' editorship were on such topics as Agriculture Information (June 1993), Rutgers Libraries Construction Projects and Library Architecture (June 1992), and the Special Commemorative Issue on the Presidents of Rutgers (June 1991). These special issues enable the Journal to deal with these topics in some detail and to appeal to various groups outside our regular audience. I will continue this practice and alternate special issues with miscellany containing a variety of articles that fall under the broad outline of the Journal's mission: scholarly articles based on holdings of Rutgers libraries, and in the areas of New Jerseyana, the history of books, libraries, and printing. We welcome the submission of articles or ideas for articles and special issues.

My hope is that I can continue the high standards of Pamela Richards, John Osborne, and the other editors that have preceded me.

Robert G. Sewell 